\title{
From inflexible national legislation to flexible local governance: management practices in the Pelister National Park, Republic of Macedonia $^{1}$
}

\author{
Saška Petrova \\ (corresponding author) \\ Institute for Environmental Studies \\ Faculty of Science \\ Charles University in Prague \\ Benatská 2, 12801 Prague 2 \\ Czech Republic \\ mcihar@natur.cuni.cz
}

\author{
Stefan Buzar \\ University of Birmingham \\ Tel: +44 (0)121 4142943 \\ Fax: +44 (0)121 4145528 \\ buzars@adf.bham.ac.uk \\ Martin Cihař \\ Institute for Environmental Studies \\ Faculty of Science \\ Charles University in Prague \\ Benatská 2, 12801 Prague 2 \\ Czech Republic \\ mcihar@,natur.cuni.cz
}

School of Geography, Earth, and Environmental Sciences

\begin{abstract}
The involvement of local people in protected area management a key factor for the sustainable and efficient protection of wildlife, and an economically preferable approach for the effective everyday care and protection of the environment. This paper aims to explore the community participation and protected area management challenges faced by national park authorities in developing countries, through a case study of the Pelister National Park in the Republic of Macedonia. The paper focuses on the multiple social, economic and political expressions of flexibility in national park management at the local scale. These examinations are based on field research in Pelister, executed in the summer of 2006, and involving 20 in-depth interviews with local policy-makers, nature protection experts and local inhabitants, as well as a questionnaire survey of 140 residents of three villages in and around the park (Nizhepole, Malovishta and Brajchino).
\end{abstract}

\footnotetext{
${ }^{1}$ Part of Stefan Buzar's background research for this paper was supported by the Ministry of Education, Youth and Sports of the Czech Republic, project no. MSM0021620831: 'Geographic Systems and Risk Processes in the Context of Global Change and European Integration'.
} 


\section{From inflexible national legislation to flexible local governance: management practices in the Pelister National Park, Republic of Macedonia}

\section{Introduction}

The conventional management system for protected areas - also known as the 'Yellowstone' model - perceives the human disruption of such environments as a causal factor for the depletion of geological and biological diversity (Pimbert et al. 1995). However, it is now widely believed that the dominance of conventional management practices has led to the displacement of local populations from protected areas, while putting unreasonable limitations on the use of natural resources in the name of nature protection (Stevens 1997, Kusumanto and Sirait 2001). As a result, the involvement of local people in protected area management is being increasingly recognised as a key necessity for the sustainable and efficient protection of wildlife, and as an economically preferable approach for the effective everyday care and protection of the environment (Pimbert et al. 1995). Indeed, as argued by Hall (2000), international development agencies have accepted co-management as an appropriate model for natural resource governance, allowing for the extensive involvement of national and local governments, civil society organisations and local communities in this process. The recognition of local participation in protected area management had led to the creation of new roles for conservation professionals and protected area authorities, requiring a fundamental re-framing of existing co-management schemes and inter-institutional arrangements (Wells and Brandon 1992, Pretty and Chambers 1993, McShane and Wells 2004).

Although the importance of local community engagement in protected area management has been widely recognised and analyzed in the academic literature having been followed by a rising involvement of local populations in rural development decisions - there is limited evidence that 'community participation has become widespread practice or been effective in influencing the nature and scale of development' (Goodall and Stabler 2000: 63). As pointed out by Pimbert et al. (1995) 'the professional challenge for protected area management is to replace the top-down, standardised, simplified, rigid and short-term with local-level diversified, complicating, flexible, unregulated and long-term natural resource management practices' (page 34). This is because, in its entirety, community participation opens the opportunity for the incorporation of 'widely different levels and qualities of involvement at the local level' (Pretty 1995: 4). Such arguments have been further supported by Defries et al. (2007), who emphasise that the extent and magnitude of human resource use in a protected area management system is related to its achievement of an effective balance between human needs and ecological functions. According to Daily and Ellison (2002) and Rosenzweig (2003), the main purpose of protected area management should be the establishment of 'win-win' solutions that satisfy human needs while maintaining ecological functions.

Moreover, most of the existing models for local community involvement in protected area management have mainly been based on the experiences of relatively stable and developed societies (Hall 2000). Many countries outside this realm still host controversial debates about the extent to which nature conservation practices should follow the 'Yellowstone' model - excluding any 'interference' from local people - or a co-management model that would accommodate development and livelihood needs 
at the same time (Stevens 1997). This is especially the case in areas where protected area management may conflict with community-based conservation and "natureaware' tourism. In practice, many developing-world countries still overwhelmingly utilise top-down management models, partly as a result of the chronic lack of research and policy awareness relating to the ecological, socio-political and economic factors that influence efficient local community participation in protected area governance, biodiversity conservation, and rural economic development more generally (Wells and McShane 2004).

Given such background conditions, this paper aims to explore the community participation and protected area management challenges faced by national park authorities in developing world countries, through a case study of the Pelister National Park in the Republic of Macedonia. We examine the micro-level articulations of management and conservation practices that characterise the behaviours of the local population and governing authorities in the park, with the aim of evaluating the 'real life' implementation of the co-management model for protected areas. Although various national-level institutions and consecutive governments have repeatedly declared their commitment to this approach, there is limited evidence for its successful implementation on the ground.

Being located in the heart of Southeastern Europe - a region that has underwent major economic, social and political changes over the last 18 years - Macedonia provides an unprecedented opportunity for studying the multiple interactions between rigid macro-level path-dependencies embedded in past and present policy documents and legal frameworks, on the one hand, and the flexible micro-level strategies and practices employed by local populations and management authorities as a method of overcoming such formal constraints, on the other. In this context, the paper focuses on the multiple social, economic and political expressions of flexibility in national park management at the local scale, arguing that a 'bottom up' co-management model has de facto already been operating in Pelister for some time, despite the lack of a de jure framework at the level of the central state.

In the analysis that follows, we highlight the different components of this 'flexible' co-management model, while contrasting them with the inflexibilities that characterise Macedonia's formal legal system for national park management. These examinations are based on field research in Pelister, executed in the summer of 2006, and involving 20 in-depth interviews with local policy-makers, nature protection experts and local inhabitants, as well as a questionnaire survey of 140 residents of three villages in and around the park (Nizhepole, Malovishta and Brajchino). The data gathered thanks to this research was interrogated with the aid of a variety of qualitative and quantitative methods, and combined with a survey of the formal legal framework and policy documents for nature protection in the country to produce two analyses that highlight, respectively, the inflexible and flexible dimensions of national park management in Pelister. These two investigations form the two core sections of the text that follows. However, they are preceded by a general overview of the human and physical geography of the national park itself.

\section{Setting the context: key features of Pelister National Park}


Pelister is the first national park in the Republic of Macedonia and one of the oldest such protected areas in the Balkans, having been founded as early as 1948. It is situated in the southwestern part of the country, adjacent to the border with Greece and less than 15 kilometres from Bitola, Macedonia's second largest city. Pelister encompasses the north parts of the Baba mountain massif, extending between altitudes of 891 and 2601 metres above sea level. Thanks to the expansion of its boundaries in 2007, the park now covers a total area of 14300 hectares (MOEPP 2007). Although the area around the park is dotted by a number of villages Brajchino, Kazhani, Rotino, Capari, Magarevo, Trnovo, Dihovo and Nizhepole - that are well known for their rich cultural and architectural heritage, Pelister's territory only includes one rural settlement - the village of Malovishta - within its boundaries, since the park extends mainly across the upper parts of the mountain. However, considering that the economies of all of these settlements are mainly based on tourism, agriculture and animal husbandry, their overall pattern of development and everyday life is heavily influenced by the path followed by the park (European Agency for Reconstruction 2003).

Pelister's geological base of is characterised by a unique combination of rocks from different eras, ranging from the Palaeozoic and Mesozoic all the way to the Quaternary. The heavily alkaline 'Pelister Granite', contained in a massive dome formation dating from the Ordovician, dominates most of the park and forms one of its key distinguishing features. This structure is embedded within a series of older, Palaeozoic green shales - another typical characteristic of Pelister's geological base. In addition, the park also contains Palaeozoic quartz- and quartz-sericite schists, as well as Mesozoic gabbro, dolerite veins, diabase and mermekitic granite. Glacial and periglacial landforms are among the main geomorphological attributes of the park, including a wide variety of relatively unusual - for this latitude at least - landforms such as cirques, moraines, granite block streams and fields, alongside nivation hollows, garlands, solifluction lobes, and ploughing blocks. Two of the cirques host tarns, which are well known throughout the country and represent a major tourist attraction.

Thanks to its varied geological systems, varied physical landscapes and pronounced mountain climate, Pelister has provided an optimal environment for the development of a wide variety of biotopes, including forests, dry grassland, mountain and freshwater ecosystems. As such, they comprise a diverse array of vegetation types, ranging from heath and scrubs to broadleaved deciduous (oak and beech) and coniferous (Macedonian pine) forests. The park's numerous rivers, tarns and other aquatic habitats support a wide range of riparian communities, while areas above $2000 \mathrm{~m}$ host alpine and sub-alpine grassland. While nine out of Pelister's thirty-two different natural habitat types (nine forest and sixteen grass communities) are protected by the Bern Convention as habitats that require special conservation measures - two of them are locally endemic communities (Pelister National Park Authority 2006). According to the Management Plan, the national park's key protection targets in this domain include:

- Species protected globally or in Europe: Canis lupus, Felis silvestris, Lutra lutra, Myotis capaccinii (mammals); Rhinolophus blasii, Rhinolophus ferrumequinum, Rhinolophus hipposideros, Alauda arvensis, Alectoris graeca, Coturnix coturnix, Emberiza cia, Falco biarmicus, Lullulaarborea, Gypaetus 
barbatus, Perdix perdix, Pyrrhocorax pyrrhocorax (birds); Salmo pelagonicus (fish); Boletus regius (mushroom);

- Species that are rare and protected in Macedonia: Andreaea rupestris, Buxbaumia viridis (mosses); Crocus pelistericus, Gentiana lutea, Gentiana punctata, Sempervium octopodes, Sempervium marmoreum, Knautia magnifica, Viola parvula (plants); Achnanthidium kryophila, Luticola undulata, Navicula roteana, Pinnularia appendiculata (algae); Chroogomphus helveticus, Suillus sibiricus ssp. Helvetica (mushrooms); Parmelia exasperatula, Parmelia sorediata, Ramalina carpatica (lichens);

- Endemic species: Alchemila peristerica, Dianthus myrtinerviu (plants); Niphargus pancici pancici, Eucypris kurtdiebeli (animals); Duvalius macedonicus, Duvalius peristericus, Tapinopterus comita, Nebria aetolica macedonica, Tapinopterus monastirensis monastirensis and Trechus goebli goebli (insects).

Among the key distinguishing features of Pelister National Park are the substantial Macedonian pine (Pinus Peuce) forests - locally known as 'molika' (Nastov 1994, 2000). Covering a relatively large share of the park's northern slopes, Pelister's pine forests are among the Balkans' best-developed and most extensive ecosystems formed by this otherwise extremely rare and endemic pine. The 'molika' forms two different types of vegetation communities on the territory of the park: mountainous woodland (Digitali viridiflorae - Pinetum peuces) found at altitudes ranging from 900 and 1600 metres above sea level; and sub-alpine woodland (Gentiano luteae-Pinetum peuces), usually present between 1500 and 2100 or more metres.

\section{Macedonia's formal legal framework for nature protection: path-dependent inflexibilities}

Since gaining independence in 1991, and as a result of its aspirations to become a EU member, the Republic of Macedonia has continuously worked on the harmonisation of its internal legal framework with EU legislation (European Commission 1996, 2005). Moreover, the universal right to a healthy environment for enshrined in the country's constitution, which obliges all of its citizens to respect environmental and nature protection principles (GRM 1991). But these issues have traditionally received little policy attention and priority in the country, as evidenced by the fragmented and insufficiently comprehensive character of legislation relating to the management of protected areas, in addition to the lack of coherent, continuous, and integrated scientific work on the subject.

An important step towards the improvement of this situation was made in 2004, which saw the adoption of a new Law on Nature Protection. The Law, which aimed to achieve comprehensive natural heritage conservation, protection and management, allowed for the implementation of internationally recognised and ratified conventions in this domain, while transposing EU legislation regarding nature protection to the Macedonian content (GRM 2004). In recent years, the legislative framework for nature protection has been expanded to comprise the Law on the Environment, as well as sectoral laws regulating the use of natural resources in particular domains, 
including the fishing (GRM 1993), hunting (GRM 2004), forestry (GRM 2004), pastures (GRM 2000), and plant protection (GRM 2000).

At the same time, the state has taken numerous steps to ratify international conventions and agreements on nature protection. The long list of such documents includes: the UNESCO Convention concerning the protection of the world cultural and natural heritage; the Rio de Janeiro Convention on biological diversity; the Ramsar Convention on wetlands; the Bern Convention on the conservation of European wildlife and natural habitats; the Agreement on African Euroasian migratory wetland birds; the Bonn Convention on the Conservation of Migratory Species of Wild Animals; the Cartagena protocol on biosafety; the Agreement on Bat Protection (EUROBATS); the Convention on International Trade in Endangered Species of Wild Fauna and Flora (CITES), and the Convention for the Protection Vertebrate Animals Use for Experimental and Other Scientific Purposes. Moreover, the Law on Nature has incorporated the two key European directives regarding nature protection: the Council Directive 79/409/EEC on the Conservation of wild birds and Directive 92/43 EEC on the Conservation of natural habitats of wild fauna and flora.

In addition to the increasingly thick file of legal acts, Macedonia has also formulated a formal Strategy and Action Plan on biodiversity protection. These documents are meant to provide policy instruments for expert support towards effective nature protection and management. While the Strategy defines the integral approach towards nature protection and sustainable use of specific biological resources, the Plan describes concrete activities that should be realised according to the main purposes of the Strategy. The Plan also contains a set of additional management tools, which should allow for the preparation and implementation of secondary regulation documents (i.e. protected area management plans), thus completing the legislative base for efficient nature protection and sustainable management.

One of the main purposes of the Law on Nature is to provide for the establishment and management of a system of protected areas aimed at maintaining biological and landscape diversity. Thus, the categorisation and zoning of protected areas in the country has been implemented in line with IUCN (International Union for the Conservation of Nature) criteria. The Law defines six categories of protection: $i$ ) strict nature reserve, ii) national park, iii) natural monument, iv) nature park, v) protected landscape and $v i$ ) multipurpose area. It stipulates that each protected area may contain a zone of: $i$ ) strict protection, ii) active management, iii) sustainable use and $i v$ ) buffering. The total size of all areas protected through the Law has reached 187,770 ha (around 8 per cent) of the country's territory, including three national parks with a total surface area of around 108,338 ha.

As far as national parks are concerned, it is worth noting that the structure of their management system is highly hierarchical, with a two-way information system. Through the Ministry of Environment and Physical Planning (MOEPP), the government acts as an executive body responsible for the creation, management and protection of national parks. However, the day-to-day governance of such areas is carried out by national park authorities - public institutions established by the Government, in accordance with the provisions of the Law on Nature and the act for the creation of the given national park. The Law on Nature also defines the structure of the authorities, which include a management board, director, an expert advisory 
board and a board for financial oversight. Their main responsibilities include: $i$ ) implementing the statutes of the national park; ii) adopting and implementing of the national park management plan and annual programme and iii) formulating a financial plan for the park. The direct protection of the park is carried out by a specialised ranger service - established or designated by the park authority - while the efficiency of the authority itself, as well as the quality of the wider national park environment is monitored by the State Inspectorate for the Environment (see Figure 1).

Therefore, it can be concluded that the three key factors that contribute to the inflexibility of national park management and protection are: $i$ ) the lack of protected areas management plans; ii) insufficient human resources (as national park authorities are still set up as forest management companies in which environmental and social experts are absent); and iii) financial restrictions on their operation. The only flexibility of the current legislation on nature protection lies in the preparation and implementation of management plans for protected areas, defined and designed in accordance with the Law on Nature. The management plans, among other tasks, are supposed to provide opportunities for the efficient involvement of local communities in nature protection and management. However, the preparation of the management plans for protected areas is still rare in Macedonia. Currently, the only management plan is the one for Pelister. 


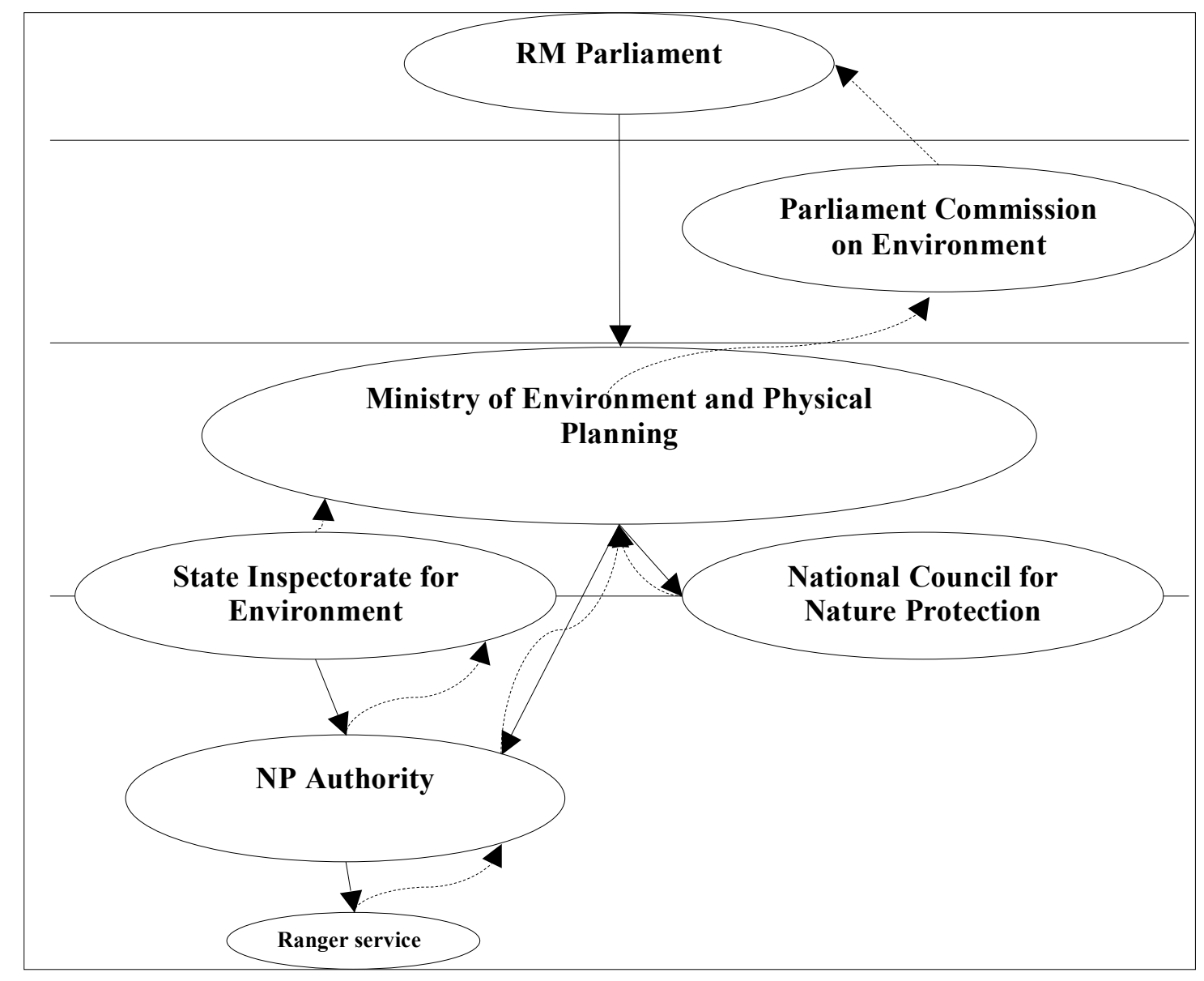

Figure 1: The national park management system in the Republic of Macedonia (continuous line $=$ competence, dashed line $=$ two-way information system). 


\section{Flexible modes and solutions}

During our fieldwork in Pelister, it emerged that Macedonia's inflexible legislation and rigid legal management structure for nature protection has compelled the national park authority to develop and implement several alternative modes for effective local participation in the management and protection of the park. The authority's efforts in this domain have mainly been concentrated on the engagement of local stakeholders in park governance, while supporting them in the establishment of representative institutions relevant to the operation of the authority. Pelister's management institutions have also aided the creation of various organisational forms that may facilitate stakeholder co-operation and involvement in its activities. In addition to these 'top down' approaches, our research also indicated that the local population employs a number of 'bottom-up' flexible participation methods in order to improve its contribution to the decision-making process, while gaining economic and social benefits from the proximity of the park. In their entirety, both types of engagement have helped improve policy formulation and implementation in the park, partly by opening the space for the co-existence of different forms of knowledge and participatory frameworks related to protection of the national park.

The importance of the authority's role in the development of an effective management and protection framework for the national park - entailing the active involvement of local communities in its day-to-day governance - is all the more pertinent in light of the fact that policy practices in this domain are increasingly influenced by political and economic processes at larger scales (Brown 2003, Barrett et al. 2001, Hanna et al. 1997, Hutton and Leader-Williams 2003). However, although global processes can be seen in locations where the livelihoods of people living in and around protected areas are influenced by global markets (Liu and Diamond 2005), local populations still play an important role in allowing protected areas to be managed in an effective and durable manner (Wells and McShane 2004).

\section{Flexible top-down approaches towards local people in the NP}

The inflexibility of formal protected area management systems is mainly reflected in the limited use of natural resources, as well as the strict delineation of movement paths in the park. Such constraints may potentially lead to major conflicts of interest and land-use struggles between local people and the state institutions responsible for managing the national park. In this context, one of the key challenges for the national park authority has been the establishment of efficient top-down management structures that can satisfy the needs and interests of local communities, while providing for national park protection.

The results of the field research in Pelister pointed to some of the more successful approaches towards local community co-operation and involvement in national park management. In general, the evidence gathered though this process contradicted the widespread perception - common within part of the literature on the subject (Castro and Nielson 2004) - that a national park can only place a burden on the everyday life of local communities. Even though Pelister does possess a fairly rigid and externally controlled formal management structure, in transpired that the national park authority has still found numerous flexible solutions, which allow local communities to benefit from its existence. Thus, the park provides a range of local services, including waste 
management, free fuelwood for heating, and the improvement and maintenance of local infrastructure - especially water supply systems - which all make a lasting and significant contribution to the strengthening of its relationship with the local population.

According to the Law on Nature, the national park authority is also responsible for the sustainable management and use of natural resources within the park. Considering that this includes non-timber forest products it means that the Authority is fully responsible for organizing the trade of, inter alia, Pinus peuce seeds, cones and blackberries. In the case of the latter, the national park issues a specific number of licences to local families every year, allowing them to pick blackberries and sell them to licensed firms. Although the fees for the licences are related to their types, several interviewees expressed concerns that their distribution may create local conflicts by favouring specific local villages and/or families, or engaging people who don't live in the national park area.

Another frequently used participation method has been the involvement of local residents as employees in national park management structures. As such, the practice has helped fortify the co-operation process between the local community and the park authority, especially in terms of improving fire precaution and protection, as well as preventing illegal forest logging. Thanks to this policy, a number of local inhabitants have been employed as full- or part-time members of the ranger service, or as foresters in the national park. In addition to such efforts, the park authority has also established and promoted local food and craftwork labels, beneficial for local communities in the development of alternative low-impact tourism in the park. Considering the significant rate of unemployment in the region (according to the Statistical Office of RM, the joblessness rate stands at around 35 per cent of the active workforce), it is hoped that development of nature-aware tourism in the park may increase the opportunities for investment in this area, preventing out-migration from local villages.

A key step in this direction was provided by the Project for the Conservation of Pelister Mountain, financially supported by the Swiss Agency for Development and Cooperation (SDC) in co-operation with MOEPP. This initiative, which was implemented in the Pelister area between 2000 and 2006, involved the establishment special project offices in Skopje and Bitola under the support of the Swiss NGO Pro Natura - Friends of the Earth. One of its main purposes was the development of sustainable tourism, including rural tourism. During the realisation of the work plan, it was concluded that Pelister's significant potential for nature-aware tourism is hampered by the park's poor infrastructure and the absence of skilled human resources. Wanting to improve the skills of the local population, the project team organised several different training and language courses in co-operation with the park management authority. They helped identify the need for official and efficient local community representation in the national park management, as well as the insufficient support towards local NGOs as mediating institutions in this context.

\section{Flexible bottom-up participatory modes}

Unfortunately, top-down management approaches do not always ensure the significant direct involvement of local people in the governance of national parks 
(McShane and Wells 2004). Without feedback mechanisms, the authorities' efforts to foster a more meaningful co-operation process with local communities might result in an unsuccessful outcome (Sinclair and Stabler 1997). Our field research in Pelister indicated that the local population has developed a number of bottom-up approaches towards the management of the park, allowing it to participate more actively in the Authority's work.

One of the most common such models was the establishment of local NGOs, aimed at increasing the local population's role in the management of the park, as well as raising awareness about nature protection and the development of nature-aware tourism. These organisations have taken responsibility for a plethora of nature protection activities, including educational seminars, field trips to the forests, as well as preparing and disseminating informative materials. In order to achieve their aims, the NGOs also organise local festivities aimed at promoting traditional food, customs, cultural activities and craftwork. In Brajchino, most of the families who are engaged in tourist services (accommodation, preparation of meals, guidance of tourists through the park) are organised in one NGO. They jointly define the prices for each service, thus reducing conflicts over price competition. Most interviewees emphasised that the NGO model has been very effective in terms of encouraging the direct participation of local people in national park structures, while ensuring that nature protection brings economic benefits for all of them.

In response to the opportunities for developing nature-aware tourism, many families from the villages in the area have rearranged their houses for tourist accommodation purposes, while establishing small enterprises for different tourist services. This strategy allows local populations to promote and develop rural tourism in a natureaware manner, in addition to strengthening the local economy and empowering citizens to become a more influential factor in the management of the park.

Furthermore, the dependence of their firms' revenues directly on tourism development - especially in terms of the number and quality of tourists - strengthens the local inhabitants' relationship with the national park. This is mainly because the growth of tourism in the area is directly related to the quality of its natural environment. Therefore, the close connection between nature protection and tourism growth provides a key incentive for local communities to participate in the projects and activities relating to the management and protection of the national park, led by relevant institutions.

The fact that nature-aware tourism is still developed unevenly and relatively poorly around the Pelister National Park area provides a useful starting point for any future analyses of the attitudes of local populations towards the park. The results of the research indicated that that the scale of tourism development in the national park is not a decisive factor in the creation of local opinions and attitudes. All three villages involved in the research have developed local tourism at a different scale, depending on the number of tourists per year and the period of their stay (although the range of differences is valid only for local circumstances). In all three villages, the respondents expressed positive attitudes towards the national park's existence, mainly as a result of the improved investment opportunities that it brings.

\section{Conclusion}


As Goodall and Stabler (1997) and Goodall (1995) have argued, a single model or strategy for nature protection and tourism development does not exist. This paper explored the local co-management and protection practices in Southeastern Europe, through a case study of the Pelister National Park in the Republic of Macedonia. We tried to identify the inflexible components that obstruct opportunities for local community participation in protected area management, while investigating the possible presence of alternative co-management models. Based on a combination of qualitative and quantitative research methods, we pinpointed the three key factors that contribute to the inflexibility of national park governance and protection: $i$ ) absence of protected area management plans; ii) insufficient and incomplete human resources and iii) financial shortages.

Despite the inflexible legislation and rigid legal management structure for nature protection, however, we also identified several successful top-down and bottom-up approaches towards local community co-operation and involvement in national park management. The leading top-down approaches in this respect include: $i$ ) free services and investment in infrastructure; ii) full- and part-time employment in the national park; iii) involvement in the trade of non-timber forest products (especially blackberries); and $i v$ ) trainings and language courses. As far as bottom-up approaches are concerned, it emerged that the area contains a number of participatory modes that allow local people to be actively involved in the National Park Authority's work. The most effective strategies of this type included the establishment of local NGOs as a tool for direct participation of local people in national park structures, the raising of public awareness about nature protection, and fundraising activities for local development. The creation of small-scale enterprises for the promotion and development of nature aware tourism was pointed out as a key factor for attracting 'high quality' tourists, thanks to its strengthening of the relationship between local people and the national park, and bringing financial benefits to both sides. The economic stability of the Pelister region is especially important in terms of preventing out-migration from the area.

In this context, it is worth noting that the national-level review of protected area governance in Macedonia indicated that top-down modes for local community participation might also be present in Pelister national park, to a minor degree at least. The results from the research weren't surprising in this regard, even though the diversity and the organisational level of top-down approaches towards local community participation exceeded our initial expectations. Taking into account the fact that protected areas in Macedonia are currently run without any management plans, the existence of bottom-up participation modes towards the governance of Pelister national park opens a new chapter in the human dimension of nature protection, not only in Macedonia, but the Balkans more widely.

\section{References:}

Barrett, C. S., Brandon, K., Gibson, C., \& Gjertsen, H., (2001). Conserving tropical biodiversity amide weak institutions. Bioscience, 51, 497-502.

Brown, K., (2003). Integrating conservation and development: a case of institutional misfit. Frontiers in Ecology and the Environment, 1, 479-487. 
Castro, P. A., \& Nielson, E., (2004). Natural resource conflict management case studies: an analysis of power, participation and protected areas. Forest Ecology and Management, 193, 427-428.

Daily, G., \& Ellison, K., (2002). The New Economy of Nature: The Quest to Make Conservation Profitable. Washington, D.C.: Island Press.

Defries, R., Hansen, A., Turner, B. L., Reid, R., \& Liu, J., (2007). Land use change around protected areas: management to balance human needs and ecological function. Ecological Applications, 17, 1031-1038.

European Agency for Reconstruction, (2003). Pelister Tourism Development Study:Development Concept Report. Thessaloniki: European Agency for Reconstruction.

European Commission, (1996). Council Decision on the Principles, Priorities and Conditions contained in the European Partnership with the former Yugoslav Republic of Macedonia. Brussels: European Commission.

European Commission, (2005). Council Decision on the Principles, Priorities and Conditions contained in the European Partnership with the former Yugoslav Republic of Macedonia. Brussels: European Commission.

Goodall, B., (1995). Environmental awareness and management response in the hospitality industry. Revista Portugese de Gestao, 2-3, 35-45.

Goodall, B., \& Stabler, M., (2000). Environmental standards and performance measurement in tourism destination development. In G. Richards, \& D. Hall (Eds.) Tourism and Sustainable Community Development. (pp 63-82). London and New York: Routledge

Goodall, B., \& Stabler, M. J., (1997). Principles influencing the determination of environmental standards for sustainable tourism. In M. J. Stabler (Ed.) Tourism and Sustainability: Principles to Practice. Wallingford: CAB International

Government of the Republic of Macedonia, (1991). Constitution of the Republic of Macedonia. Skopje: Official Gazette of the Republic of Macedonia.

Government of the Republic of Macedonia, (1993). Law on Fishing. Skopje: Official Gazette of the Republic of Macedonia.

Government of the Republic of Macedonia, (1996). National Environmental Action Plan (NEAP) Skopje: Government of the Republic of Macedonia.

Government of the Republic of Macedonia, (2000). Law on pastures. Skopje: Official Gazette of the Republic of Macedonia.

Government of the Republic of Macedonia, (2000). Law on Plant Protection. Skopje: Official Gazette of the Republic of Macedonia.

Government of the Republic of Macedonia, (2004). Law on Nature Protection. 
Skopje: Official Gazette of the Republic of Macedonia.

Government of the Republic of Macedonia, (2004). Law on Hunting. Skopje: Official Gazette of the Republic of Macedonia.

Government of the Republic of Macedonia, (2004). Law on Forestry. Skopje: Official Gazette of the Republic of Macedonia.

Hackel, J. D., (2001). Community Conservation and the Future of Africa's Wildlife. Conservation Biology, 13, 726-734.

Hall, D., (2000). Identity, community and sustainability: prospects for rural tourism in Albania. In G. Richards, \& D. Hall (Eds.) Tourism and Sustainable Community Development. (pp 48-59). London and New York: Routledge

Hanna, S. S., Folke, C., \& Maler, K. G., (1997). Rights to Nature: Ecological, Economic, Cultural, and Political Principles of Institutions for the Environment. Washington DC: Island Press.

Hough, J. L., \& Sherpa, M. N., (1989). Bottom up vs. basic needs: integrating conservation and development in the Annapurna and Michiru Mountain conservation areas of Nepal and Malawi. Ambio, 18, 434-441.

Hutton, J., \& Leader-Williams, N., (2003). Sustainable use and incentive-driven conservation: re-aligning human and conservation interests. Oryx, 37, 215226.

Kusumanto, Y., \& Sirait, M. T., (2001). Community Participation in Forest Resource Management in Indonesia: Policies, Practices, Constraints and Opportunities.Southeast Asia Policy Research Working Paper, No. 28. International Council for Research in Agroforestry (ICRAF) Southeast Asia.

Liu, J., \& Diamond, J., (2005). China's environment in a globalizing world: how China and the rest of the world affect each other. Nature, 435, 1179-1186.

McShane T.O., \& M.P., W., (2004). Getting Biodiversity Projects to Work: Towards More Effective Conservation and Development. New York: Columbia University Press.

McShane, T. O., \& Wells, M. P., (2004). Integrating protected area management with local needs and aspirations. AMBIO: A Journal of the Human Environment, $33,513-519$.

Ministry of Environment and Physical Planning (MOEPP), (2007). 'National Park Pelister with new expanded borders'. http://www.moepp.gov.mk/defaulten.asp?ItemID $=945149$ EF7760F24EA51709F8A8643C97. Accessed 1 October 2008.

Mehta J.N., \& Kellert, S. R., (1998). Local attitudes toward community-based conservation policy and programmes in Nepal: a case study in the MakaluBarun Conservation Area. Environmental Conservation, 25, 320-333. 
Nastov, A., (2000). Report of Nature Conservation in The Former Republic of Macedonia, Convention on the Conservation of European Wildlife and Natural Habitats. Strasbourg: Council of Europe.

Nastov, A., \& Micevski, B., (1994). National Report of Status of Conservation of Biological Diversity in Protected Areas of the Republic of Macedonia. Geneva and Skopje: United Nations Environment Programme (UNEP).

Pelister National Park Authority, (2006). Management Plan of Pelister National Park. Bitola: Pelister National Park Authority.

Pimbert, M. P., \& Pretty, J. N., (1995). Parks, People and Professionals: Putting 'Participation' into Protected Area Management. Discussion Paper No 57. Geneva United Nations Research Institute for Sustainable Development.

Pretty, J., (1995). The many interpretations of participation. In Focus, 16, 4-5.

Pretty, J. N., \& Chambers, R., (1993). Towards a Learning Paradigm: New Professionalism and Institutions for Sustainable Agriculture. IDS Discussion Paper 334. Brighton: Institute of Development Sudies.

Rosenzweig, M., (2003). Win-Win Ecology: How the Earth's Species can Survive in the Midst of Human Enterprise. Oxford: Oxford University Press.

Sinclair, M. T., \& Stabler, M. J., (1997). Tourism Economics. London: Routledge.

Stevens, S., (1997). The legacy of Yellowstone. In S. Stevens (Ed.) Conservation through cultural survival: indigenous peoples and protected areas. (pp 13-32). Washington, D.C.: Island Press

Wells, M. P., \& Brandon, K., (1992). People and Parks: Linking Protected Area Management with Local Communities. Washington D.C.: The World Bank.Agency for International Development and World Wildlife Fund. 